УДК 633.2.03:632.523

DOI 10.36461/NP.2020.54.1.011

\title{
ФИТОСОЦИОЛОГИЧЕСКИЙ АНАЛИЗ ОСУШАЕМОГО ЛАНДШАФТА
}

\author{
Ф. А. Мусаев, доктор с.-х. наук, профрессор; О. А. Захарова доктор с.-х. наук, доцент
}

Федеральное государственное бюджетное образовательное учреждение высшего образования «Рязанский государственный агротехнологический университет имени

П. А. Костычева», г. Рязань, Россия, e-mail: ol-zahar. ru@yandex.ru

Кормовая значимость лугов, используемых в качестве сенокосов и пастбищ, снижается от произрастания на них ядовитых растений. К ядовитым относятся растения, поедание которых вызывает у животных серьезные отравления, а в некоторых случаях приводит к гибели животных. Ядовитость обусловлена содержанием в них особых химически активных действующих соединений. Цель исследований - проведение геоботанического обследования луга на территории мелиоративного объекта Тинки-ІІ на землях Рязанской Мещеры для определения ботанического состава луговых трав, выявления и степени обилия на нем ядовитых растений. Местоположение луга - близ д. Полково Рязанского района Рязанской области. Обследование проведено на площади 10000 м $^{2}$ в июле 2019 года при предварительном рекогносцировочном осмотре территории по ходу рабочих маршрутов. Методика исследований общепринятая. В результате проведенного обследования территории установлены растения доминанты Elytrígia repens и Alopecurus pratensis с частой встречаемостью и высокой степенью обилия. В результате изучения растительного покрова на обследуемом участке луга выделена ассоциация Elytrígetum urtícetosum. Растения произрастали сплошным ковром и покрытие почвы составляло до $100 \%$. Общее количество ядовитых растений составило 102 экземпляра из 6 семейств. Наиболее часто встречающиеся ядовитые растения представлены семействами Зонтичные (Apiaceae) и Лютиковые (Ranunculaceae). Доля участия каждого ядовитого компонента: Conium maculatum - $36 \%$, Chaerophyllum temulum, Cicuta virosa - $29 \%$, Oenanthe aquatica, Thalictrum aquilegiifolium - $15 \%$, Caltha palustris, Anemone ranunculoides $-8 \%$, Calla palustris, Pedicularis palustris, Glechoma hederacea, Persicaria hydropiper - по $12 \%$. Таким образом, видовой состав луговых трав обеднен и мала вероятность отравления сельскохозяйственных животных, так как наличие ядовитых растений незначительно, с учетом их негативного влияния на организм животного только при определенной дозе и сроке экспозиции.

Ключевые слова: луг, осушительная система, деградированная торфяная почва, ядовитые растения, отравление.

\section{Введение}

Кормовая значимость лугов, отведенных под сенокосы и пастбища, снижается от произрастания на них ядовитых растений $[6,12]$. Для эфффективного использования природных лугов специалистам сельского хозяйства необходимы подробные сведения об их хозяйственном состоянии $[7,13]$. В бывшем СССР для животноводства за счет мелиорации производилось до $40 \%$ кормов. В каждом хозяйстве были геоботаническая, почвенная и агрохимическая оценки природных и сеяных сенокосов и пастбищ, используемых в кормовых целях. Сенокосные угодья обследовались перед сенокошением, что позволяло получить материал, наиболее полно их характеризующий. Для пастбищ описание проводилось в более ранние сроки, перед началом выпаса скота. В СССР в обязанность агрономов, зоотехников и ветеринарных врачей входило обследование кормовых угодий и проведение мероприятий по уничтожению ядовитых растений. В современном сельскохозяйственном производстве, к сожалению, подобные мероприятия проводятся нерегулярно $[4,6]$.

К ядовитым относятся растения, поедание которых у животных вызывает серьезные отравления организма, а в некоторых случаях приводит к их гибели. Ядовитость (токсичность) растений обусловлена содержанием в них особых химически активных действующих соединений: алкалоидов, гликозидов, сапонинов, органических кислот (щавелевой, синильной), лактонов, токсальбуминов (фитотоксины - рицин, робин), эфирных масел (терпены, камфора), красящих веществ (госсипол, гиперицин), смолистых веществ и других [8].

Ядовитые начала, попав в организм животных, действуют по-разному: одни преимущественно на центральную нервную систему, другие - на пищеварительный 
тракт, третьи - на сердце, половую деятельность, солевой обмен. Вред от ядовитых растений зависит от многих причин, и, в первую очередь, от содержания токсикантов, которые накопились к определенной фазе онтогенеза растений $[6,9,11]$.

Животные ранней весной, вследствие жадного и неразборчивого поедания пастбищной травы, содержащей в своем составе ядовитые растения, подвергаются отравлению [2]. Это связано с тем, что в свободном от пищи желудке голодных животных быстрее и в большем количестве всасываются яды, что и обуславливает более тяжелое течение отравления. Позднее взрослые животные ведут себя на выпасе осторожно и, как правило, не поедают ядовитых растений из-за жгучего или неприятного вкуса и запаха растений [5], но возможность отравления молодняка остается высокой.

Сохранение биологического разнообразия растений, их естественного возобновления требует рассмотрения вопросов, в которых проявляется многоликость растительных организмов, в частности, таксономических, биоморфологических, онтогенетических, экологических и иных. Видовой состав фрлоры многих регионов России изучен достаточно полно [7], но, по мнению авторов статьи, вызывает особый интерес обследование луга на длительно функционирующих (с конца 1955-го г. до настоящего времени) мелиоративных системах, которые сейчас пришли в упадок и деградируют.

\section{Методы и материалы}

Цель исследований - проведение геоботанического обследования луга на мелиоративном объекте Тинки-ІІ на территории Рязанской Мещеры для определения ботанического состава луговых трав, степени обилия и выявления на нем ядовитых растений.

Мелиоративный объект организован в конце 1950-х гг. близ д. Полково Рязанского района Рязанской области. Сообщение с областным центром - автомагистраль. Землепользование на 2018 г. содержало 4114,6 га, из них болота - 60 га, осушительная система размещена на 40 га + 30 га осушительно-увлажнительной сети, которая в 2000-х гг. прекратила существование с сохранением одностороннего регулирования водного режима территории при отводе воды в открытый осушительный коллектор или непосредственно магистральный канал. Но регулировать водный баланс в настоящее время проблематично из-за отсутствия на данном участке осушительной сети шлюза-регулятора, демонтированного несколько лет назад [4].
Методика исследований - согласно известным публикациям $[1,4,11]$. По земельному плану авторами был установлен вид луга и его фрактическое использование (в настоящее время только для выпаса скота жителями деревни). Обследование проведено с 15 по 30 июля 2018 г. и с 27 июля по 8 августа 2019 г. при предварительном рекогносцировочном осмотре территории по ходу рабочих маршрутов в рамках мониторинга деградированных торфяных почв Рязанской Мещеры, проводимого авторами с 2005 по настоящее время. Тип растительной группировки - злаковоразнотравное.

Участок исследований граничит с одной стороны с жилыми домами д. Полково, с другой - лесополосой, с третьей - с магистральным осушительным каналом и с четвертой - с открытым осушительным коллектором. Площадь участка обследования 100 x 100 м была разбита на квадраты 10 x 10 м. Обследованный участок мелиоративной системы все еще входит в состав экополигона. При оценке культуртехнического состояния участка луга зарегистрирована небольшая закочкаренность (покрытие кочками незначительное, их происхождение связано с развитием корневой системы трав), почва излишне влажная, другие особенности обследуемой части луга не установлены.

Уклон участка измеряли методом вешек с жесткой рейкой и уровнем с последующим расчетом на онлайн-калькуляторе тригонометрических фрункций. Величину уклона і рассчитывали по формуле

$$
\mathrm{i}=\Delta \mathrm{h} / \mathrm{L} \text {, }
$$

где $\Delta \mathrm{h}$ - высотная разница отметок соседних характерных точек, м; L - расстояние между соседними характерными точками, м.

Условия рельефа участка характеризовались уклонами и их направлениями. На плане (рис. 1) отметки горизонталей заложены с падением по высоте, или шагом, 1 м. Уклон, определенный выражением (1), равен 0,0002. Наивысшие линии хребтов являются водораздельными, а по наиболее низким участкам лощин, называемых тальвегами (или нагорно-ловчими каналами), концентрируется сток поверхностных вод. Характер водоразделов и тальвегов определяется разностью наиболее высоких и низких отметок, частотой горизонталей на отдельных участках и степенью их выпуклости или вогнутости, характеризующей продольный уклон и крутизну откосов и склонов. Рельеф спокойный (рис. 1, 2).

Торфяный горизонт разделяется на подгоризонты в зависимости от ботаниче- 
ского состава растений, составляющих торф, и от степени его разложения. Профииль осушенной торфяной почвы мелиоративного объекта Тинки-ІІ подразделяется на генетические горизонты от Ао до Bg, подстилаемые средне-зернистым, насыщенным водой желтым песком.

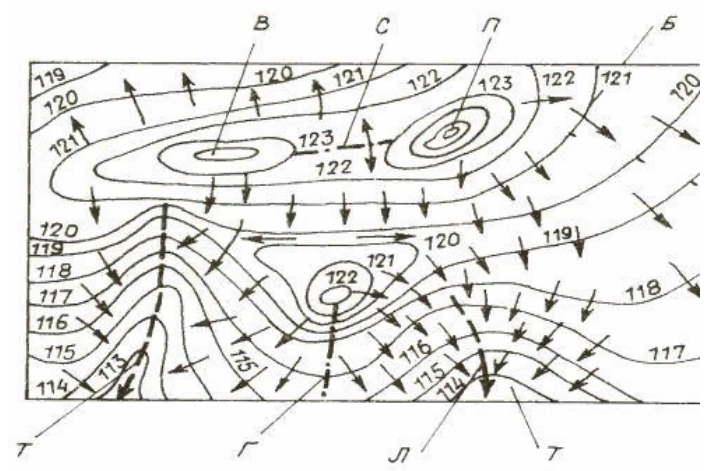

Рис. 1 План местности с отметками рельефра:

B - вершина, C - седловина, П-пик Б, указывающий направление склона,

$P$ - равнинный участок, $T$ - тальвег, Л-лощина, Г- гребень. Стрелки показывают направление поверхностного стока в сторону магистрального канала

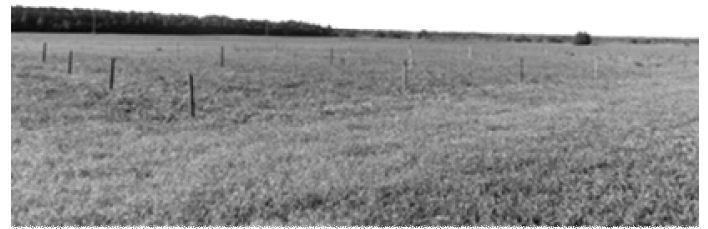

Рис. 2. Общий вид участка обследования луга

Замеры УГВ проведены с помощью хлопушки в открытых смотровых колодцах. Водное питание объекта - атмосферногрунтовое. Грунтовые воды вскрыты на глубине 90-120 см [3, 6]. Торфяные подземные пожары отмечаются ежегодно.

Обследования проводились на различных уровнях организации растительных систем: организменном, популяционно-видовом, ценотическом.

Ботаническая ревизия проведена с использованием ботанических определителей [1], обилие видов - по Друде на следующий день после выпадения осадков. Почва относится к категориям от сырой (16\% площади центральных квадрантов) до мокрой (84 \% площади ближе к пограничным квадрантам), то есть сырая почва при сжатии кома выделяла капельно-жидкую воду, просачивающуюся между пальцами. Из стенок разреза слабо истекала вода; мокрая почва содержала воду, соответствующую ее полной влагоемкости.

При полевых ботанических исследованиях была изучена фрлора мелиоративного объекта, то есть проведено флористическое исследование, которое позволило составить флористический список растений. В соответствии с методикой вначале проведен обход участков по отложенным сторонам, переписаны все растения, а уже потом - два пункта внутри них. Помимо ботанического описания проведен количественный учет видов и их соотношения по Друде с использованием степеней обилия:

- soc. (sociales) - данное растение образует фон, встречаясь в массах, причем надземные части смыкаются;

- cop. (copiosae) - растение встречается в больших количествах, однако не доминирует и фона не дает с выделением трех ступеней сор. 3, сор. 2, сор. 1; по степени убывания обилия - очень обильно, обильно, довольно обильно; однако все же в случае большого обилия (cop. 3) доминирования не наблюдается;

- sp. (sparsae) - растение встречается в небольших количествах, вкраплено в основной фон из растений предыдущих категорий;

- sol. (solitariae) - встречается в очень малых количествах, единичными экземплярами;

- un. (unicum) для растений, которые на данной площадке встречаются в единственном экземпляре.

Основной систематической (таксономической) единицей при описании растительности является ассоциация, объединяющая сообщества растений, сходные по видовому составу, структуре (обилие и размещение видов по площади) и однородные по требованиям к условиям местообитания [1, 11]. Количество зеленой массы луговых трав определялось взвешиванием на аналитических весах при скашивании растений вручную серпом.

Тепловлагообеспеченность резко менялась по годам, часто наблюдались отклонения от среднемноголетних величин в сторону засухи, отмечались ежегодные суховеи, а большинство осадков носили ливневый характер.

Компьютерные и математические методы статистического анализа данных реализованы в универсальной интегрированной системе визуализации результатов исследований Statistica 10 [2]. При работе в программе использованы опции Statistics и Graphs. 


\section{Результаты}

Жизненная форма растительности на участке определялась по Раункиеру и Серебрякову как гемикрипто-, крипто- и терофиты. На состав фритоценоза оказали влияние экологические фракторы, например, климатические (свет, тепло, воздух, вода), топографические (влияние рельефа), эдафические (свойства почвы), биотические (влияние на растений и животных), антропогенные (деятельность человека), исторические (геологические изменения поверхности Земли). Наиболее заметно влияние на растения климатических фракторов, особенно воды [2, 10, 13]. Несмотря на искусственное отведение воды в пределах осушительной системы, водный режим остается слабо регулируемым из-за отсутствия ухода за элементами осушительной сети. Все описанные растения участка луга относились к мезо- (от греч. mesos - средний, промежуточный) и гигрофритам (от греч. hihros - влажный), которые способны выдерживать высокую влажность почвы.

В задачи исследований не входила кормовая оценка травостоя, что характерно при геоботаническом описании сенокоса или пастбища, поэтому авторами растения не распределялись по хозяйственным группам, выделяя злаки, бобовые, разнотравье.

Геоботаническое описание травянистого сообщества включало описание общих сведений о расположении участка:

- географическое положение (область, район, населённый пункт) - Рязанская, Рязанский, Полково;

- геоморфологические условия: рельеф спокойный, уклон i $=0,002$, микрорельеф. Наблюдались малочисленные растительные кочки, по величине относящиеся к категории карликовых. Покрытие площади кочками составляло 2-5 шт./м², что по градации относится к слабой закочкаренности;

- почва - деградированная торфяная низинного болота, на 80-91 \% состоящая из органического вещества разной степени разложения: слабой - $20 \%$, средней - 20$40 \%$, хорошей 40-50 \% и выше; содержание гумуса и гуминовых веществ до $60 \%$, в зависимости от степени разложения торфа. В связи с этим поглотительная способность высокая, достигала 118 миллиэквивалентов на 100 г почвы (для примера, у черноземных - 30-40). Запас доступной влаги в метровом верхнем слое значительный. Почва способна прочно удерживать значительную часть поглощенной воды; гигроскопическая влажность достигала $18-20 \%$ от абсолютно сухого веса, а влажность устойчивого завядания, практически неиспользуемая растениями часть поглощенной воды, составляла 36-40 \% от полной влагоемкости. Степень разложения торфа от 20 до 50 \%, что являлось критическим и свидетельствовало о превращении его в гумифицированную массу, которая при дальнейшем использовании может деградировать все больше и привести к полной сработке торфяной почвы. Зольность - от 11,5 до 14,5 \% и объемная мас-

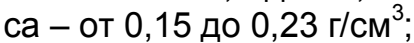

- аспект, то есть физиономия луга на момент обследования - серовато-зеленый с незначительными вкраплениями белорозового по краям участка за счет цветков разнотравья. Жизненность растений определена в три балла - нормально цветут и плодоносят на момент обследования. Общее покрытие до $98 \%$. Напочвенный покров травянистый. Травостой на участке очень густой и испарение с поверхности почвы сводится к минимуму;

- хозяйственное использование фитоценоза - кормовое (для домашнего скота).

Результаты ботанического обследования луга сведены в таблице 1.

По данным, представленным в таблице, установлены растения-доминанты: Elytrígia répens и Alopecúrus praténsis с час-

Таблица 1

Ботаническая сводка обследуемого участка мелиоративного объекта Тинки-ІІ

\begin{tabular}{|c|c|c|c|c|c|}
\hline \multicolumn{2}{|c|}{ Название вида } & \multirow{2}{*}{$\begin{array}{c}\text { Средняя } \\
\text { высота, см }\end{array}$} & \multirow{2}{*}{$\begin{array}{l}\text { Встреча- } \\
\text { емость }\end{array}$} & \multirow{2}{*}{$\begin{array}{c}\text { Обилие } \\
\text { по Друде }\end{array}$} & \multirow{2}{*}{$\begin{array}{c}\text { Название } \\
\text { ассоциации }\end{array}$} \\
\hline Русское & Латинское & & & & \\
\hline Пырей ползучий & Elytrígia répens & 114 & 98 & SOC & \multirow{8}{*}{ 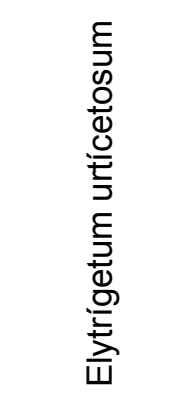 } \\
\hline Лисохвост луговой & Alopecúrus praténsis & 88 & 47 & cop. 1 & \\
\hline $\begin{array}{l}\text { Льнянка } \\
\text { обыкновенная }\end{array}$ & Linaria vulgaris & 46 & 49 & $\begin{array}{c}\text { сор. } 1 \\
\text { куртинками }\end{array}$ & \\
\hline Крапива двудомная & Urtíca dióica & 89 & 68 & cop. 3 & \\
\hline Мятлик болотный & Poa palustris & 60 & 60 & cop. 3 & \\
\hline Овес посевной & Avéna satíva & 67 & 34 & sol. - sp. & \\
\hline \begin{tabular}{|l|} 
Канареечник \\
тростниковидный
\end{tabular} & Phalaris arundinacea & 80 & 67 & cop. 3 & \\
\hline Тимофеевка луговая & Phleum pratense & 78 & 39 & sol. - sp. & \\
\hline
\end{tabular}


Ботанический состав растений-торфообразователей в торфе обследуемого участка луга

\begin{tabular}{|l|l|c|c|}
\hline \multicolumn{2}{|c|}{ Растение-торфообразователь, название вида } & \multicolumn{2}{c|}{ Содержание в торфе, \% } \\
\hline \multicolumn{1}{|c|}{ Русское } & \multicolumn{1}{|c|}{ Латинское } & $\begin{array}{c}\text { древесно- } \\
\text { травяном }\end{array}$ & травяном \\
\hline Камыш озерный & Schoenoplectus lacustris & 10 & \\
\hline Тростник обыкновенный & Phragmites australis & 12 & 15 \\
\hline Хвощ лесной & Equisetum sylvaticum & 12 & 8 \\
\hline Пушица многоколосковая & Eriophorum polystachyon & 20 & 25 \\
\hline Болотница маленькая & Eleocharis quinqueflora & 10 & 10 \\
\hline Осока заостренная & Carex acuta & 20 & 35 \\
\hline Кора и древесина хвойных & Cortice et ligno deciduis species & 6 & 5 \\
\hline Кора и древесина лиственных & Cortice et ligno conifers & 10 & 5 \\
\hline
\end{tabular}

той встречаемостью и высокой степенью обилия. Эти растения остались как представители сеяного луга в прошлом. В результате изучения растительного покрова на обследуемом участке луга выделена ассоциация Elytrígetum urtícetosum.

Анализ ботанического состава двух проб торфа, отобранных близ лесополосы и в центре обследуемого участка, показал соответствие торфу низинного болота и его высокую степень разложения. Выявлены различия по ботаническому составу растений-торфообразователей. Основу составили древесно-травяной и травяной торфы, но преобладали остатки травянистых растений - до $87 \%$, остатки древесных растений составляли лишь $13 \%$ (табл. 2), что характерно для прошлой истории ландшафта.

Глазомерно с использованием специальной рамки определялся процент поверхности почвы, покрытый наземными частями каждого вида растений. Растения произрастали сплошным ковром и, как отмечено выше, покрытие почвы составляло до $98 \%$. Травостой густой. На $1 \mathrm{~m}^{2}$ насчитывалось в среднем 500 (в центральных квадрантах)-1000 растений.

Основная масса корней случайно отобранных растений (70-80 \%) у многолетних трав располагалась на глубине до $20 \mathrm{~cm}$, образуя густое сплетение корней, а на поверхности почвы - дернину.

Взвешивание (в среднем) зеленой массы луговых трав на аналитических весах в пересчете на $1 \mathrm{~m}^{2}$ показало урожай в 5,236 кг.

На обследуемом участке были выявлены ядовитые растения в малых количествах или с единичной встречаемостью. Их видовой состав изменялся в зависимости от удаленности от открытых каналов, обеспечивающих подпитку почвенному грунту:

- ближе к откосам магистрального канала или открытого осушительного коллектора - болиголов пятнистый (Conium macu- latum), бутень одуряющий (Chaerophyllum temulum), василистник водосборолистный (Thalictrum aquilegiifolium), ветреница лютиковая (Anemone ranunculoides). Ввиду отсутствия работ по скашиванию растительности на откосах и бермах каналов произошло зарастание древесно-кустарниковой растительностью;

- ближе к центру участка - белокрыльник болотный (Calla palustris), вех ядовитый (Cicuta virosa), мытник болотный (Pedicularis palustris),

- в непосредственной близости к жилым домам - будра плющевидная (Glechoma hederacea), бутень одуряющий (Chaerophyllum temulum), вех ядовитый (Cicuta virosa), горец перечный (Persicaria hydropiper), калужница болотная (Caltha palustris), омежник водяной (Oenanthe aquatica).

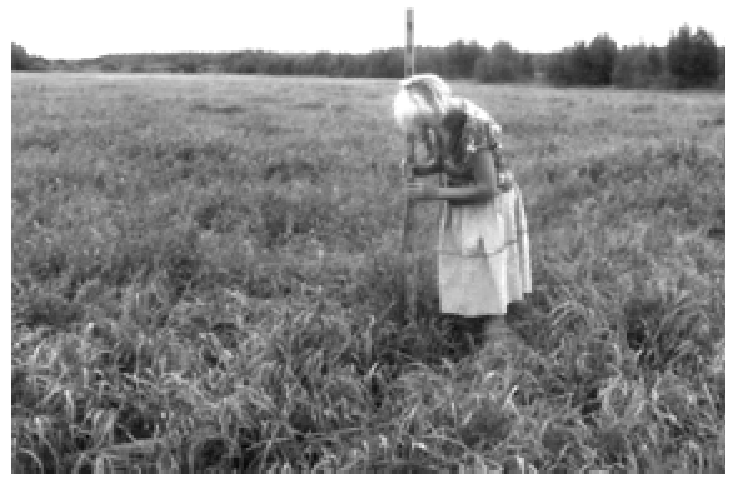

Рис. 3. Измерение высоты трав

Проведенный регрессионный анализ показал зависимость между высотой растений (рис. 3), произрастающих в разной удаленности от источника воды, в частности, открытых магистрального канала и коллектора. Уравнение имело вид: $\mathrm{y}=48,6$ $+0,15 x$.

При произрастании ядовитых растений в непосредственной близости к жилым домам зависимость оказалась недостоверной $(p=0,2)$. По-видимому, оказывали влияние 
Частотное распределение высоты ядовитых травянистых растений по месту произрастания (выборочные измерения)

\begin{tabular}{|c|c|c|c|c|}
\hline Интервал & $\begin{array}{c}\text { Количество } \\
\mathrm{n}\end{array}$ & $\begin{array}{l}\text { Кумулятивное } \\
\text { количество } \mathrm{n}_{\text {кум }}\end{array}$ & $\begin{array}{c}\text { Процент } \\
\text { встречаемости В }\end{array}$ & $\begin{array}{l}\text { Кумулятивный } \\
\text { процент } \mathrm{N}_{\text {кум }}\end{array}$ \\
\hline \multicolumn{5}{|c|}{$\begin{array}{l}\text { Ядовитая трава ближе к откосам магистрального канала } \\
\text { или открытого осушительного коллектора }\end{array}$} \\
\hline $57,400 \leq x<58,000$ & 2 & 2 & 13,33333 & 13,3333 \\
\hline $58,000 \leq x<59,000$ & 9 & 11 & 60,00000 & 73,3333 \\
\hline $59,000 \leq x<60,000$ & 4 & 15 & 26,66667 & 100.0000 \\
\hline \multicolumn{5}{|c|}{ Ядовитая трава ближе к центру участка } \\
\hline $56,700 \leq x<57,000$ & 2 & 2 & 13,33333 & 13,3333 \\
\hline $57,700 \leq x<58,000$ & 12 & 14 & 80,00000 & 93,3333 \\
\hline $59,000 \leq x<60,000$ & 1 & 15 & 6,66667 & 100,0000 \\
\hline \multicolumn{5}{|c|}{ Ядовитая трава в непосредственной близости к жилым домам } \\
\hline $62,8375 \leq x<56,0625$ & 9 & 9 & 60,00000 & 60,0000 \\
\hline $65,0625 \leq x<56,2875$ & 5 & 14 & 33,33333 & 93,3333 \\
\hline $67,2875 \leq x<57,5125$ & 1 & 15 & 6,66667 & 100,0000 \\
\hline
\end{tabular}

дополнительные источники питания, например, хозяйственно-бытовые отходы, которые нивелируют подобную зависимость, что отображается на выравненности растений по высоте. На это также указывало частотное распределение высоты растений: если максимальная высота ядовитых растений была установлена ближе к жилому сектору или магистральному каналу или открытым коллекторам в 12 случаях из 15 (80\%) в одном интервале 57-59 см, то у растений, произрастающих ближе к центру участка, таких интервалов было два: 56-57 см (60\%) и 57-59 см (27\%) (табл. 3).

Результаты регрессионного анализа высоты растений были бы необходимы при сельскохозяйственном использовании луга для работы косилок-измельчителей.

Растения, составляющие фитоценоз, различны по величине и располагаются в несколько ярусов, которые являются сложными. Ярус более крупных растений называется первым, в него входят такие высокорослые ядовитые растения, как, например, Thalictrum aquilegiifolium; растения, вторые по величине, образуют второй ярус, к примеру, Conium maculatum. Кроме надземной ярусности, существует подземная, благодаря чему растения наиболее полно используют воду и минеральные вещества. Так, глубина корневой системы Thalictrum aquilegiifolium максимальна по сравнению с Anemone ranunculoides. Условия существования растений первого яруса значительно отличаются от условий, в которых находятся растения нижних ярусов; растения первого яруса поглощают большую часть солнечных лучей, тогда как растения нижележащих ярусов затенены; сила ветра, условия аэрации, температурные условия совершенно иные. Поэтому виды, экологически равноценные, располагаются в одном ярусе, а экологически различные в разных ярусах. Ярусность во времени, обусловленная различной жизненной ритмикой растений, входящих в разные ярусы, авторами во внимание не принималась вследствие краткосрочной ревизии луга.

Bce вышеперечисленные ядовитые растения по шкале Друде относились к степени обилия solitariae или unicum.

Убывающий количественный ряд ядовитых растений расположен следующим образом: Caltha palustris $\leq$ Cicuta virosa $\leq$ Persicaria hydropiper < Chaerophyllum temulum < Glechoma hederacea < Oenanthe aquatica $<$ Conium maculatum $=$ Pedicularis palustris $=$ Chaerophyllum temulum $=$ Thalic trum aquilegiifolium $=$ Anemone ranunculoides = Calla palustris.

Conium maculatum, Chaerophyllum temulum, Cicuta virosa, Oenanthe aquatica относятся к семейству Зонтичные (Apiaceae), Thalictrum aquilegiifolium, Caltha palustris, Anemone ranunculoides - Лютиковые (Ranunculaceae), Calla palustris - Ароидные, или Аронниковые (Araceae), Pedicularis palustris - Заразиховые (Orobanchaceae), Glechoma hederacea - Яснотковые (Lamiaceae), Persicaria hydropiper - Гречишные (Polygonaceae).

По 8-15 экземпляров было обнаружено Caltha palustris, Cicuta virosa, Persicaria hydropiper, Chaerophyllum temulum, Glechoma hederacea, которые можно отнести к рудеральным. Численность остальных видов значительно меньше (рис. 4).

Общее количество ядовитых растений составило всего лишь 102 экземпляра из 6 семейств. Больше ядовитых растений представлено семействами Зонтичные 


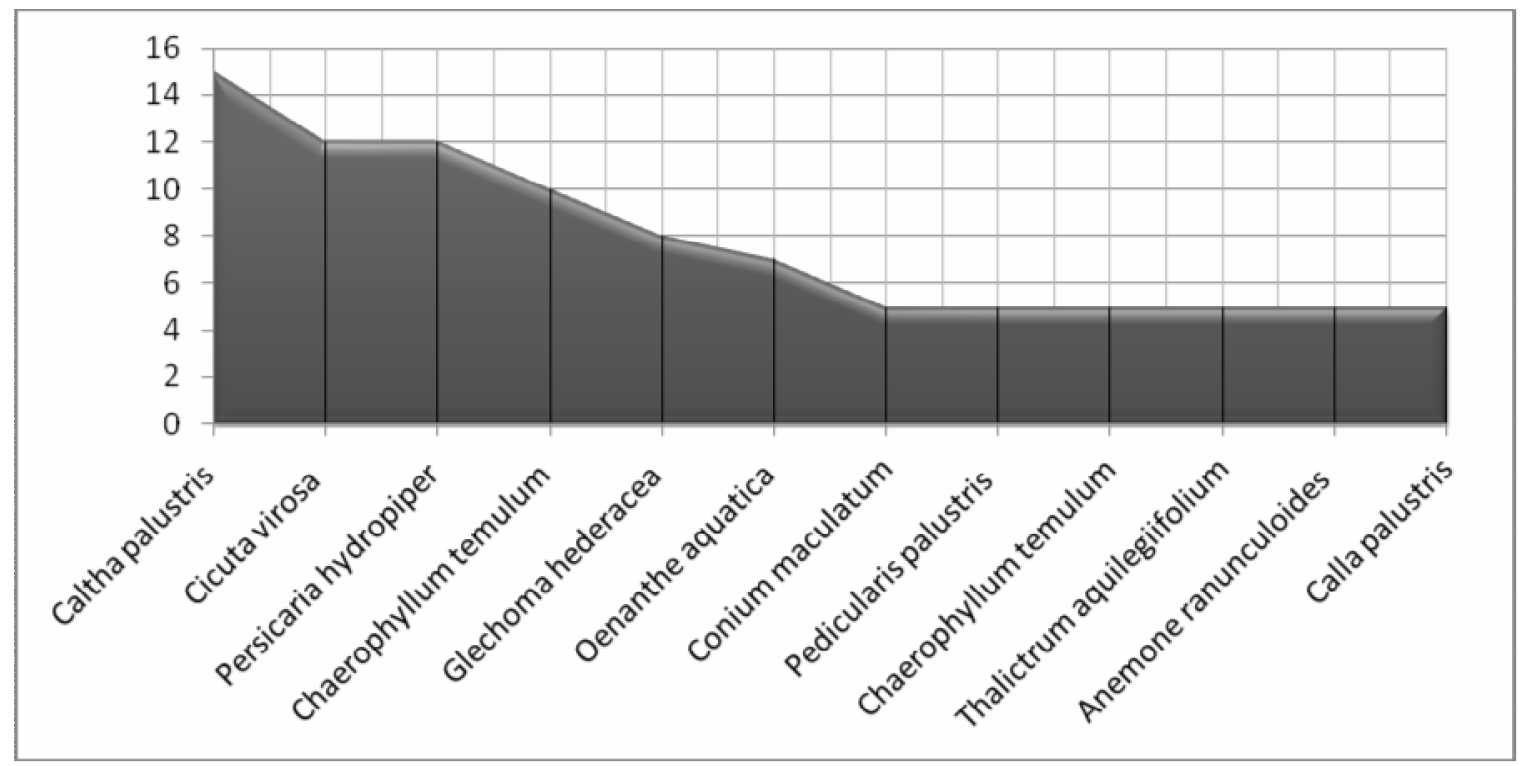

Рис. 4. Распределение ядовитых травянистых растений по численности, экз.

(Apiaceae) и Лютиковые (Ranunculaceae). Доля участия каждого ядовитого компонента следующая: Conium maculatum - 36 \%, Chaerophyllum temulum, Cicuta virosa $29 \%$, Oenanthe aquatica, Thalictrum aquilegiifolium - $15 \%$, Caltha palustris, Anemone ranunculoides $-8 \%$, Calla palustris, Pedicularis palustris, Glechoma hederacea, Persicaria hydropiper - по $12 \%$.

В ассоциации видовая насыщенность невысокая и составляет лишь 20 видов, что согласуется с известными данными по торфяным почвам [3, 4]. Разнообразие видов возрастает к границам обследуемого участка луга. Так, в центральных квадрантах обнаружено лишь 8-10 видов, а на пограничных участках - по 15-18 видов.

Bce вышеизложенные этапы обследования участка луга относятся к основным определяющим признакам фритоценоза.

Многие ядовитые растения в малых дозах являются лекарственными, как, например, Persicaria hydropiper, Thalictrum aquilegiifolium и другие. А такие растения, как Pedicularis palustris и другие, относятся к группе вредных, вызывающих при поедании сельскохозяйственными животными порок продукции (изменение цвета, запаха, вкуса, консистенции).

Надо обратить внимание, что обследуемый авторами участок луга не использовался в сельскохозяйственном производстве длительное время и сейчас находится под угрозой исчезновения, несмотря на то, что территория не была затронута весенним травяным палом, даже глазомерно заметна деградация исходного сеяного луга [6]. Это является следствием резкого ухудшения работы осушительной системы, изменения водно-мелиоративных и агрохимических свойств торфяной почвы в результате прекращения возобновления органического вещества минеральными и органическими удобрениями, недостатка доступного травам азота, применения севооборотов и вторичного заболачивания территории.

В процессе исследований выявлена тенденция постепенного вытеснения неядовитых растений ядовитыми, входящими в группу гигрофитов (Conium maculatum, Chaerophyllum temulum, Thalictrum aquilegiifolium, Caltha palustris, Oenanthe aquatic $и$ другие), мезофитов (Glechoma hederacea, Chaerophyllum temulum, Cicuta virosa и другие), что косвенно свидетельствует об изменении водного режима территории и проявлении вторичного заболачивания изза высокого стояния грунтовых вод.

Таким образом, геоботаническое обследование участка луга на мелиоративной системе Тинки-ІІ проведено с позиции системного подхода, представляющего собой совокупный, взаимосвязанный, пропорциональный анализ всех фракторов, путей и методов решения сложной задачи.

\section{Заключение}

Анализируя результаты обследования участка луга площадью 10000 м², можно сделать выводы:

- произошло формирование ассоциации травянистых растений Elytrígetum urtícetosum;

- выявлены растения-доминанты Elytrigia repens и Alopecurus pratensis с частой встречаемостью и высокой степенью обилия;

- торф имеет высокую степень разложения. В торфе преобладают остатки тра- 
вянистых растений до $87 \%$, остатки древесных растений составляют лишь $13 \%$;

- присутствует обедненность видового состава луговых трав; выявлено 12 видов ядовитых растений из 6 семейств; по шкале Друде количество ядовитых растений относится к степени обилия solitariae - встречается в очень малых количествах, единичными экземплярами или unicum - для растений, которые на данной площадке встречаются в единственном экземпляре;

- существует малая вероятность отравления сельскохозяйственных животных вследствие незначительного количества ядовитых растений и с учетом их негативного влияния на организм животного толь- ко при определенной дозе и сроке экспозиции.

Обследуемый участок можно оценить, по мнению авторов, как хороший, состоящий из многолетних высокоценных в кормовом отношении трав; однолетники редки. Ежегодные обследования природных кормовых угодий, планирование и применение комплекса мер по их улучшению и правильному использованию могут дать большой хозяйственный эффект, повысить продуктивность с одновременным улучшением качества получаемого корма, полностью или в значительной степени избавиться от ядовитых растений.

\section{Лumepamypa}

1. Борисова, И. В. Изучение аспективности растительных сообществ / И. В. Борисова // Проблемы современной ботаники. - Т.1. - Москва; Ленинград: Наука, 1965. - С. 291-295.

2. Боровиков, В. П. Statistica: искусство анализа данных на компьютере / В. П. Боровиков. Санкт-Петербург: Питер, 2001. - 656 с.

3. Зайдельман, Ф.Р.Генезис и экологические основы мелиорации почв и ландшафтов / Ф. Р. Зайдельман. - Москва: КДУ, 2009. - 720 с.

4. Ботаническое обследование осушенной торфяной почвы Рязанской Мещеры / О. А. Захарова, К. Н. Евсенкин, Л.М. Захаров, Т. А. Кудрявцева // Комплексный подход к научнотехническому обеспечению сельского хозяйства: материалы Международной научнопрактической конференции (Международные Бочкаревсие чтения), посвященной памяти членакорреспондента РАСХН и НАНКР, академика МАЭП и РАВН Бочкарева Я. В. - Рязань: Рязанский государственный агротехнологический университет, 2019. - С. 343-346.

5. Захарова, О. А. Использование инновационных методов обучения в преподавании ботаники / О. А. Захарова // Вестник Рязанского государственного агротехнологического университета им. П. А. Костычева. - 2014. - № 1 (21). - С. 36-40.

6. Захарова, О. А. Режим органического вещества в мелиорированной почве / О. А. Захарова, Я. В. Костин. - Рязань: РГАТУ, 2013. - 116 с.

7. Маевский, П. Ф. Флора средней полосы Европейской части России / П. Ф. Маевский. - Москва: Товарищество научных изданий КМК, 2006. - 600 с.

8. Ядовитые растения кормовых угодий и их воздействие на организм сельскохозяйственных животных / Ф. А. Мусаев, О. А. Захарова, Н. И. Морозова, Я. В. Костин. - Рязань: РГАТУ, 2013. $150 \mathrm{c}$.

9. Олейникова, Е. М. Стержнекорневые травы юго-востока средней России: диссертация на соискание ученой степени доктора биологических наук / Е. М. Олейникова. - Воронеж, 2014. $400 \mathrm{c.}$.

10. Campbell, B. D. An experimental test of plant strategy theory / B. D. Campbell, J. P. Grime // Ecology. - 1992. - V. 73. - № 1. - P. 15-29.

11. Falinska, K. Genet disintegration in Filipendula ulmaria: consequences for population dynamics and vegetation succession / K. Falinska // Ibid. - 1995. - V. 83. - P. 9-21.

12. Grame, J. P. Comparative plant ecology / J. P. Grame, J. G. Hodgson, R. Hunt. - London: Unwin Human, 1988. - 739 p.

13. Körner, C. Functional Plant Ecology of High Mountain Ecosystems/ C. Körner // Alpine Plant Life. - Berlin: Heidelberg, 2003. - P. 424-430. 


\title{
PHYTOSOCIOLOGICAL ANALYSIS OF THE DRAINED LANDSCAPE
}

\author{
F. A. Musaev, Doctor of Agricultural Sciences, Professor; \\ O. A. Zakharova, Doctor of Agricultural Sciences, Associate Professor
}

Federal State-Funded Educational Institution of Higher Education Ryazan State Agrotechnological University by P. A. Kostychev, Ryazan, Russia, e-mail: ol-zahar. ru@yandex.ru

The fodder value of meadows used as hayfields and pastures decreases because of the growth of poisonous plants on them. Poisonous plants are those that cause serious poisoning in animals that consume them, and in some cases it leads to death of the animals. The toxicity is due to the content of special reactive compounds in them. The research objective is to conduct a geobotanical survey of the meadow on the territory of the Tinky-II reclamation site on the lands of the Ryazan Meshchera to determine the botanical composition of meadow grasses, to identify and determine the abundance of poisonous plants on it. The location of the meadow is near the village of Polkovo, Ryazan district, Ryazan region. The survey covered the area of $10,000 \mathrm{~m}^{2}$ in July 2019 during a preliminary reconnaissance survey of the territory along the working routes. The research methodology is generally acknowledged. As a result of the territory survey, it was established that the dominant plants are Elytrígia repens and Alopecurus pratensis, that occur frequently and have a high degree of abundance. As a result of studying the vegetation cover, the association Elytrígetum urtícetosum was distinguished in the examined area of the meadow. The plants grew with a continuous carpet and the soil cover was up to $100 \%$. The total number of poisonous plants was 102 from 6 families. The most common poisonous plants are represented by the Apiaceae and Ranunculaceae families. The share of each poisonous component: Conium maculatum - $36 \%$, Chaerophyllum temulum, Cicuta virosa - $29 \%$, Oenanthe aquatica, Thalictrum aquilegiifolium - $15 \%$, Caltha palustris, Anemone ranunculoides - $8 \%$, Calla palustris, Pedicularis palustris pa riceprica, hydrachlecha - $12 \%$ each. Thus, the species composition of meadow grasses is depleted and there is little chance of poisoning of farm animals, since the presence of poisonous plants is insignificant, taking into account their negative impact on the animal's body only at a certain dose and duration of exposure.

Key words: meadow, drainage system, degraded peat soil, poisonous plants, poisoning.

\section{Reference:}

1. Borisova, I. V. Study of the Aspectivity of Plant Communities / I. V. Borisova // Problems of Modern Botany. - T.1. - Moscow; Leningrad: Nauka, 1965. - P. 291-295.

2. Borovikov, V. P. Statistica: the art of data analysis on a computer / V. P. Borovikov. - St. Petersburg: Peter, 2001. $-656 \mathrm{p}$.

3. Zaidelman, F. R. Genesis and ecological fundamentals of land reclamation of soils and landscapes / F. R. Seidelman. - Moscow: KDU, 2009. - 720 p.

4. Botanical examination of the dried peat soil of the Ryazan Meshchera / O. A. Zakharova, K. N. Evsenkin, L. M. Zakharov, T. A. Kudryavtseva // Integrated approach to scientific and technical support of agriculture: materials of the International scientific and practical conference (International Bochkarev reading), dedicated to the memory of the corresponding member of RAAS and NANKR, academician of MAEP and RAVN Bochkarev Y. V. - Ryazan: Ryazan State Agrotechnological University, 2019. - P. 343-346.

5. Zakharova, O. A. Using innovative teaching methods in teaching botany / O. A. Zakharova // Bulletin of the Ryazan State Agrotechnological University by P. A. Kostychev. - 2014. - No. 1 (21). - P. 36-40.

6. Zakharova, O. A. Regime of organic matter in reclaimed soil / O. A. Zakharova, Ya. V. Kostin. Ryazan: RGATU, 2013. - $116 \mathrm{p}$.

7. Maevsky, P. F. Flora of the middle zone of the European part of Russia / P. F. Mayevsky. - Moscow: Partnership of scientific publications of KMK, 2006. -600 p.

8. Poisonous plants of forage land and their effect on the body of farm animals / F. A. Musaev, O. A. Zakharova, N. I. Morozova, Ya. V. Kostin. - Ryazan: RGATU, 2013. - 150 p.

9. Oleinikova, E. M. Stem root herbs of the southeast of central Russia: a dissertation for the degree of Doctor of Biological Sciences / E. M. Oleinikova. - Voronezh, 2014. - 400 p.

10. Campbell, B. D. An experimental test of plant strategy theory / B. D. Campbell, J. P. Grime // Ecology. - 1992. - V. 73. - № 1. - P. 15-29.

11. Falinska, K. Genet disintegration in Filipendula ulmaria: consequences for population dynamics and vegetation succession / K. Falinska // Ibid. - 1995. - V. 83. - P. 9-21.

12. Grame, J. P. Comparative plant ecology / J. P. Grame, J. G. Hodgson, R. Hunt. - London: Unwin Human, 1988. $-739 \mathrm{p}$.

13. Körner, C. Functional Plant Ecology of High Mountain Ecosystems / C. Körner // Alpine Plant Life. - Berlin: Heidelberg, 2003. - P. 424-430. 